\title{
Spatiotemporal variability of sedimentary organic matter supply and recycling processes in coral reefs of Tayrona National Natural Park, Colombian Caribbean
}

\author{
E. Bayraktarov ${ }^{1, *}$ and C. Wild ${ }^{1,2}$ \\ ${ }^{1}$ Coral Reef Ecology Group (CORE), Leibniz Center for Tropical Marine Ecology (ZMT), Bremen, Germany \\ ${ }^{2}$ Faculty of Biology and Chemistry (FB2), University of Bremen, Bremen, Germany \\ * present address: Global Change Institute, The University of Queensland, Brisbane, Australia \\ Correspondence to: E. Bayraktarov (elisa.bayraktarov@uni-bremen.de)
}

Received: 5 November 2013 - Published in Biogeosciences Discuss.: 18 December 2013

Revised: 24 April 2014 - Accepted: 24 April 2014 - Published: 6 June 2014

\begin{abstract}
Sediments are fundamental for the function of oligotrophic coral reef ecosystems because they are major places for organic matter recycling. The Tayrona National Natural Park (TNNP, Colombian Caribbean) is located between the population center Santa Marta (> 455000 inhabitants) in the southwest and several river mouths in the east. Here, coral reef sediments experience pronounced changes in environmental conditions due to seasonal coastal upwelling, but knowledge of relevant spatiotemporal effects on organic matter supply to the sediments and recycling processes is not available. Therefore, sediment traps were deployed monthly over 14 months complemented by assessment of sedimentary properties (e.g., porosity, grain size, content of particulate organic matter and pigments) and sedimentary $\mathrm{O}_{2}$ demand (SOD) at water-current-exposed and sheltered sites along distance gradients $(12-20 \mathrm{~km})$ to Santa Marta and the eastern river mouths $(17-27 \mathrm{~km})$. Findings revealed that seasonal upwelling delivered strong (75-79\% of annual supply) pulses of labile organic matter mainly composed of fresh phytoplankton detritus ( $\mathrm{C}: \mathrm{N}$ ratio 6-8) to the seafloor. Sedimentary chlorophyll $a$ contents and SOD increased significantly with decreasing distance to the eastern rivers, but only during upwelling. This suggests sedimentary organic matter supply controlled by nutrient-enriched upwelling waters and riverine runoff rather than by the countercurrent-located city of Santa Marta. Organic matter pulses led to significantly higher SOD (more than $30 \%$ ) at the water-current-sheltered sites as compared to the exposed sites, ensuing a rapid recycling of the supplied labile organic matter in the permeable silicate reef sands.
\end{abstract}

\section{Introduction}

Marine shelf sediments are the major sites for mineralization and nutrient regeneration of organic matter derived from pelagic primary production and terrestrial input (reviewed by Arndt et al., 2013). A fraction of $25-50 \%$ of the organic matter derived from coastal primary production is deposited to the sediments (Nixon, 1981; Wollast, 1991; Jørgensen, 1996). The oxic surface layer of marine shelf sediments is restricted to a depth of only a few millimeters $-1 \mathrm{~cm}$ at the sediment surface (Rasmussen and Jørgensen, 1992; Kühl and Jørgensen, 1994; Arnd et al., 2013), but can account for more than half of the total organic carbon mineralization (Jørgensen and Revsbech, 1989; Köster et al., 2000). The remaining organic carbon is degraded by anaerobic processes such as nitrate, manganese, iron, and sulfate reduction, followed by methanogenesis and/or fermentation (Henrichs and Reeburgh, 1987). However, much of the sedimentary oxygen uptake in fine-grained coastal sediments is used to reoxidize the reduced products of anaerobic respiration (Canfield, 1993). The biogeochemical processes in the oxic sediment layer play an important role for highly permeable, carbonate sediments in coral reefs (Boucher et al., 1994; Alongi et al., 1996; Werner et al., 2006; Huettel et al., 2014). The efficiency of sedimentary organic matter remineralization largely depends on the properties of sediment e.g., grain size (Zobell, 1938; Newell, 1965; Meyer-Reil, 1986), permeability (Webb and Theodor, 1968; Precht and Huettel, 2004; Rusch et al., 2006), carbonate content (Capone et al., 1992; Rasheed et al., 2003), sorption capacity (Sansone et 
al., 1987; Wang and Lee, 1990), and the quality of supplied organic matter. Organic matter quality can be characterized by the lability to degradation and its $\mathrm{C}: \mathrm{N}$ content close to the Redfield ratio of 6.6 for fresh phytoplankton detritus, but typically between $6-8$ for phytoplankton of the open ocean and intertidal flats (e.g., Canfield et al., 2005). Lability of organic matter usually follows the trend small soluble molecules $>$ pigments $\gg$ lipids $>$ amino acids $>$ carbohydrates (MeyerReil, 1986; Henrichs, 1992; Wakeham et al., 1997; Fenchel et al., 1998). Lignin from terrestrial plants belongs to the most refractory organic materials (Hedges et al., 1988; Canfield, 1994). Old and partly degraded organic matter will have a higher $\mathrm{C}: \mathrm{N}$ ratio as the limiting $\mathrm{N}$ is preferentially used up by marine organisms (Canfield et al., 2005).

Reef sediments are typically derived from the calcareous skeletons of corals processed by bio-eroding organisms, but also by other biological, chemical and physical processes (Glynn, 1997; Hallock, 1997). They are usually highly permeable, have large grain sizes (Huettel et al., 2003; Rasheed et al., 2003), and are associated with many heterotrophic microorganisms (Wild et al., 2006) involved in the recycling of organic matter. In contrast, silicate sands are usually less permeable and host lower numbers of microorganisms due to their lower specific surface area as compared to carbonate sands (Rasheed et al., 2003; Wild et al., 2005b). Generally, permeable reef sediments function as biocatalytical filters that lead to a very effective processing and regeneration of organic matter (Wild et al., 2004a, 2005a, b, 2008). Consequently, these sediments contribute to the release of the limiting nutrients $\mathrm{N}$ and $\mathrm{P}$ after remineralization of organic material (Rasheed et al., 2002). Natural pulses of organic matter (Glud et al., 2008; Wild et al., 2008) that may lead to eutrophication and diseases (Fabricius, 2005) are rapidly degraded and thereby disposed.

Through their contribution to an efficient element cycling (Rasheed et al., 2002; Wild et al., 2004a), reef sediments are crucial for the functioning of coral ecosystems and help to maintain the typically high biomass and primary productivity in coral reefs (Hatcher, 1988; Sorokin, 1993), despite of the surrounding oligotrophic waters (Crossland and Barnes, 1983; Kleypas et al., 1999; Veron, 2000).

The investigation of sedimentary properties and processes in coral reefs is important for regions where agricultural activity, riverine discharge or seasonal upwelling lead to surplus nutrient concentrations, which in turn may stimulate phytoplankton blooms and an ensuing high supply of organic matter to and accumulation in the sediments (Calvert, 1987). In Tayrona National Natural Park (TNNP), at the northeastern coast of Colombia, phytoplankton primary production is influenced by seasonal change through alternating rainy and dry seasons, and a seasonal upwelling (Salzwedel and Müller, 1983; Andrade and Barton, 2005; Paramo et al., 2011). In addition, particularly during the rainy season, phytoplankton growth can be stimulated by riverine discharge of several smaller river mouths in the east (Rio Piedras,
Mendihuaca, Guachaca, Buritaca, Don Diego, and Palomino) along a distance gradient of $17-27 \mathrm{~km}$ from the TNNP bays, while a seasonal upwelling changes the physical parameters (temperature, salinity, and water currents) in the water column and leads to an enrichment of inorganic nutrients for primary production (Franco-Herrera et al., 2006; Arévalo-Martínez and Franco-Herrera, 2008; García-Hoyos et al., 2010; Ramírez-Barón et al., 2010; Paramo et al., 2011; Bayraktarov et al., 2014a). Furthermore, due to topographical orientation, the strong winds from the northeast that induce seasonal coastal upwelling have a stronger impact on all western flanks of the TNNP bays, leading to an increased exposure to waves and water currents as compared to the eastern, sheltered flanks (Werding and Sánchez, 1989; Bayraktarov et al., 2013). In addition to the river mouths in the east, the TNNP is located at a distance gradient of $12-20 \mathrm{~km}$ to the population center Santa Marta with $>455000$ inhabitants (DANE, 2005) and an extensive harbor area in the southwest that may have effects on organic matter supply and recycling processes in TNNP reef sediments.

Despite these spatiotemporal changes and potential key influences, no studies have addressed their potential effects on sedimentary properties and processes. To our knowledge, studies on the organic matter supplied and recycling processes of coral reef sediments are neither available for the Caribbean nor for any upwelling-influenced coral reefs. Therefore, a comprehensive monthly monitoring of sedimentary status and process variables was performed over 15 months at wind-, wave- and water-current-exposed and sheltered sites in the four major TNNP bays Chengue, Gayraca, Neguanje, and Cinto. In addition, in one exemplary TNNP bay (Gayraca), the supply of particulate organic carbon and nitrogen (POC and PON) and chlorophyll (chl) $a$ from the water column to the seafloor was assessed over 14 months using sediment traps, while grain size distribution, porosity, carbonate content, concentrations of particulate organic matter (POM) and chl $a$ in the sediments, as well as sedimentary $\mathrm{O}_{2}$ demand (SOD) as a proxy for organic matter recycling were measured at all sampling locations.

\section{Materials and methods}

Environmental monitoring of sedimentary processes was accomplished in the TNNP bays Chengue, Gayraca, Neguanje and Cinto, at a water-current-exposed site on the western flank and a sheltered site on the eastern flank of each bay (Fig. 1). The sampling sites of the present study are identical with the sites where a hydrographic survey was performed in order to assess the indicators for seasonal upwelling (Bayraktarov et al., 2014a). The sampling sites with different exposure were chosen based on studies demonstrating the difference in water current dynamics between the western and the eastern sides of the bays (Bayraktarov et al., 2013, 2014b). Water current velocities at a depth of 8-10 m were between 
3.9 and $7.4 \mathrm{~cm} \mathrm{~s}^{-1}$ with statistically significant differences (stronger water currents at the exposed than at the sheltered site) during the months of non-upwelling (Bayraktarov et al., 2014b).

\subsection{Assessment of sedimentary organic matter supply}

Organic matter reaching the seafloor was measured monthly between January 2012 and February 2013 at exemplary sites in Gayraca Bay (Fig. 1). Custom-made sediment traps consisting of $40 \mathrm{~cm}$ long PVC (polyvinyl chloride) cylinders with a diameter of $5.7 \mathrm{~cm}$ and closed lower ends were constructed. Traps were deployed in triplicate at each of the two sites in Gayraca at a water depth of $10 \mathrm{~m}$ directly in the local coral reefs by attaching them to metal rods that were inserted into the seafloor for the period of study. Traps were always at $5 \mathrm{~cm}$ over the sea bottom and at approximately $10 \mathrm{~m}$ apart from each other. The deployment time was $48 \pm 2 \mathrm{~h}$. After collection, sediment traps were tightly closed in situ and brought upright to the boat where the water with collected suspended material was decanted into $1.8 \mathrm{~L}$ clean plastic containers and transported on ice and in darkness to the laboratory for immediate processing. Aliquotes from the homogenized total trap contents were filtered on precombusted glass fiber filters (VWR International; diameter: $25 \mathrm{~mm}$, nominal particle retention: $0.7 \mu \mathrm{m})$ for POC $(0.1 \mathrm{~L})$, PON $(0.1 \mathrm{~L})$, and chl $a$ analyses $(0.1 \mathrm{~L})$. Filters with particulate trap material for POM determination were dried for at least $48 \mathrm{~h}$ at $40^{\circ} \mathrm{C}$ and stored dry and in darkness until analysis. Dried filters for POC analysis were acidified with sterile $1 \mathrm{~N} \mathrm{HCl}$ until gas production ceased (assessed visually and acoustically) in order to remove the small remaining carbonate grains from the particulate material, as described by Nieuwenhuize et al. (1994), and subsequently dried for $48 \mathrm{~h}$ at $40^{\circ} \mathrm{C}$ prior to measurements. Determinations of POC and PON were conducted by an elemental analyzer (EURO EA 3000, EuroVector, Radavalle, Italy). Carbon and nitrogen contents were derived from calculations using elemental standards (acetanilide: containing $71.05 \pm 0.18 \% \mathrm{C}$ and $10.42 \pm 0.13 \% \mathrm{~N}$, HEKAtech GmbH, Wegberg, Germany). Filters for chl $a$ were frozen at $-20^{\circ} \mathrm{C}$ and kept in the dark until extraction. Each filter was extracted using $6 \mathrm{~mL} 90 \%$ acetone for $24 \mathrm{~h}$ at $4{ }^{\circ} \mathrm{C}$ in the dark. Measurements were performed by a fluorometer (excitation filter 436FS10, emission filter 680FS10; 10AU ${ }^{\mathrm{TM}}$ Field Fluorometer, Turner Designs, Sunnyvale, USA) according to the non-acidification method of Arar and Collins (1997).

\subsection{Assessment of sedimentary properties}

Monitoring of sedimentary parameters took place in monthly intervals between December 2011 and February 2013. Sampling water depths were between 10.0 and $14.5 \mathrm{~m}$ depending on sediment availability in the bays. Sediments for porosity determination and grain size analysis were

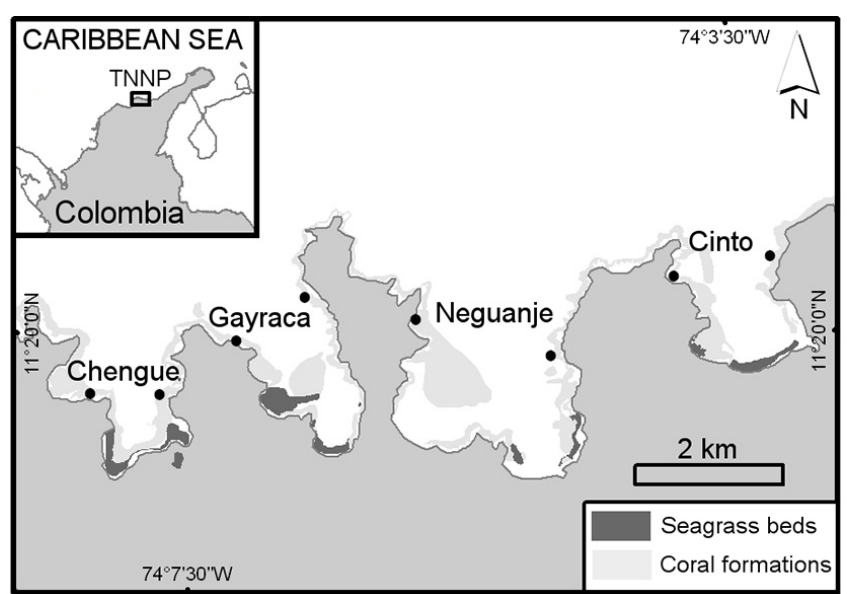

Figure 1. Bays of Tayrona National Natural Park (TNNP). Displayed are Chengue, Gayraca, Neguanje and Cinto and the sampling locations at the western (water-current-exposed sites) and the eastern (water-current-sheltered sites) flanks of each bay. Source: Invemar (2012).

collected during major upwelling in 2011/2012 and nonupwelling in 2012 by a custom-made rectangular PVC corer $(30 \mathrm{~cm} \times 15 \mathrm{~cm} \times 10 \mathrm{~cm})$ from a sediment depth of $2 \mathrm{~cm}$ ( $n=3$ per site and sampling) and transported in plastic ziplock bags to the laboratory. Subsamples of sediment (ca. $200 \mathrm{~g}$ wet weight) were desalinized with distilled water and dried at $80^{\circ} \mathrm{C}$ for at least $24 \mathrm{~h}$. Grain size was determined by sieving dry sediment samples of a known weight through a calibrated sieve stack (mesh sizes of 2000, 1000, 500, 250, 125, 63, and including $<63 \mu \mathrm{m}$ fraction) for $10 \mathrm{~min}$ by a sieve shaker (Analysette, Fritsch, Rudolstadt, Germany) and weighted. Porosity was calculated from weight loss of a known volume of wet and desalinized sediment after drying at $80^{\circ} \mathrm{C}$ for at least $24 \mathrm{~h}$ according to Higgins and Thiel (1988). Sediment samples $(n=3$ for POM and $n=3$ for chl $a$ per site and month) were collected by custom-made cores consisting of cutoff syringes with diameters of $2.9 \mathrm{~cm}$. Sediment cores containing the first $1 \mathrm{~cm}$ depth fraction of marine sediment with a surface area of $6.61 \mathrm{~cm}^{2}$ were sealed by rubber stoppers in situ and transported to the laboratory on ice and dark. For POM analysis, sediment samples were dried for at least $48 \mathrm{~h}$ at $40^{\circ} \mathrm{C}$ and stored dry and in darkness until analysis. Prior to analysis, all samples were homogenized by a grinder (Planetary Micro Mill Pulverisette 7, Fritsch, Rudolstadt, Germany) for $3 \mathrm{~min}$. Subsamples of 15$20 \mathrm{mg}$ of the ultra-fine sediment were preweighted in silver cups for POC and aluminum for PON determination. POC samples were acidified several times with $1 \mathrm{~N} \mathrm{HCl}$ to remove carbonate particles from the sediment according to Nieuwenhuize et al. (1994) and dried at $40^{\circ} \mathrm{C}$ for at least one week prior to analysis. Elemental analyses of POC and PON in sediment samples were conducted as described above. Carbonate $\left(\mathrm{CaCO}_{3}\right)$ content was determined by subtraction of 
organic carbon content from POC analyses from total carbon determined by PON analyses.

For chl $a$ extraction, sediment samples were freeze-dried overnight (Christ Alpha 1-4LD Freeze dryer, SciQuip Ltd, UK) and homogenized in the dark by pestle and mortar. A subsample of $1 \mathrm{~g}$ from each homogenized sediment sample was weighted in $10 \mathrm{~mL}$ centrifuge tubes and subsequently treated with $7 \mathrm{~mL}$ of cold $90 \%$ acetone. The samples were thereafter subjected to pulsed ultrasonic treatment $(80 \%$ amplitude, $70 \mathrm{~W}$, for 2 min with pulses of $1 \mathrm{~s}$, Bandelin 3100 Ultrasonic Homogenizer with M72 tip, vials on ice). Extraction was completed at $4{ }^{\circ} \mathrm{C}$ for $24 \mathrm{~h}$ in the dark. Prior to measurements with a UV/VIS (ultraviolet/visible) spectrometer (Lambda $35 \mathrm{UV} /$ Vis Spectrometer, Perkin Elmer) at wavelenghts of 630, 647664 and $750 \mathrm{~nm}$, samples containing algal pigments extracts were centrifuged for $10 \mathrm{~min}$ at $5000 \mathrm{rpm}$ (revolutions per minute) and $4^{\circ} \mathrm{C}$ (Centrifuge 5804R, Eppendorf, USA). Determination of chl $a$ was accomplished according to the trichroic equation of Jeffrey and Humphrey (1975) by the non-acidification method by Arar (1997).

\subsection{Quantification of sedimentary oxygen consumption}

Rates of SOD were measured after a modified incubation method by Wild et al. (2010). Therefore, sediment was sampled by the custom-made cores described above and until a maximum of $1 \mathrm{~cm}$ sediment depth ( $n=4$ per site and month) in order to assess the place where freshly supplied organic matter in the sediment surface layer arrives and is rapidly turned over by microbes via oxic respiration. Preliminary test measurements revealed that no bioturbating meiofauna was present in the sediment samples, indicating that bioturbation was very low. Seawater required for incubations was sampled with a clean black neoprene bag of $25 \mathrm{~L}$ volume at a water depth of $10 \mathrm{~m}$ and sealed under water. Concentrations of dissolved $\mathrm{O}_{2}$ were measured prior to and after incubation with a portable meter (HQ40d, Hach, Loveland, USA) with a luminescent dissolved oxygen optode (LDO101-01, Hach, Loveland, USA) immediately after sampling and on the boat. Prior to measurements, the $\mathrm{O}_{2}$ optode was calibrated in $100 \%$ water-saturated air according to the manufacturer's instructions. Subsamples of the freshly sampled seawater $(n=4$ per site and month) were taken by $80 \mathrm{~mL}$ glass jars and sediment fractions carefully inserted. Glass jars were closed to avoid any introduction of air and incubations were run in dark cooling boxes filled with ambient seawater for $8 \pm 2 \mathrm{~h}$. The experiments were conducted in closed, non-mixed incubation containers. At the end of each incubation, the seawater was thoroughly stirred in order to destroy any concentration gradients that had developed during incubation. Incubation temperature was kept constant by a temperature controller with a sensor (STC-1000, SainSonic Inc) and an attached aquarium heater (H-229, HOPAR, Guangdong, China), and never exceeded $\pm 2{ }^{\circ} \mathrm{C}$ relative to in situ seawater tempera- ture. Temperature of water during incubation was monitored by a HOBO Pendant temperature/light logger (Onset Computer Corp., Bourne, USA). Net SOD rates were calculated for each glass jar by dividing the difference between initial and end $\mathrm{O}_{2}$ concentrations by incubation time and subtracting the seawater controls determined in $60 \mathrm{~mL}$ Winkler bottles ( $n=4$ per site and month) as described above. Negative rates of sediment $\mathrm{O}_{2}$ uptake were transformed to absolute numbers and converted into $\mathrm{mmolO}_{2} \mathrm{~m}^{-2} \mathrm{~d}^{-1}$. Oxygen concentrations during dark incubations decreased by 21 (mean) to $47 \%$ ( $\max )$ during the incubation time of $8 \mathrm{~h}$. The final oxygen concentrations never went below $50 \%$ saturation, thus a linear decline could be assumed.

\subsection{Statistical data analyses}

Seasonal time intervals of the TNNP used for statistical analyses of sedimentary parameters were major upwelling season (major dry season, December-April), minor nonupwelling season (minor rainy season, May-June), minor upwelling season (minor dry season, July-August), and major non-upwelling season (major rainy season, SeptemberNovember) in accordance with the long-term hydrographical survey by Bayraktarov et al. (2014a) and further supported by Salzwedel and Müller (1983), Bula-Meyer (1990), Diaz-Pulido and Garzón-Ferreira (2002), and Andrade and Barton (2005). For analyses of sedimentation of POC, PON and chl $a$ along with measurements of porosity and grain size distributions, the seasonal time intervals were pooled to upwelling (major and minor upwelling) and non-upwelling (major and minor non-upwelling). For analyses of sedimentation rates, only parameters measured in Gayraca Bay were used.

The design and statistical analyses of the present study are consistent with methods used in long-term environmental monitoring and assessments, e.g., on water quality (Wear and Tanner, 2007; Bayraktarov et al., 2014a). Seasonality and differences due to exposition to waves and water currents of the sampling locations were examined by a permutation multivariate analysis of variance (PERMANOVA; Anderson, 2001; Anderson et al., 2008). Analyses were performed with seasonal means of sedimentation variables (supply of POC, PON and chl $a$ to the sediment), sedimentary parameters (chl $a, \mathrm{POC}, \mathrm{PON}, \mathrm{CaCO}_{3}$, and $\mathrm{SOD}$ ), and sediment characterization (grain size and porosity).

Univariate PERMANOVAS were performed for each sedimentation and sedimentary variable, and sediment characterization, separately in order to identify significant differences between seasons, bays and exposure (Table 1). For the sedimentary variables chl $a, \mathrm{POC}, \mathrm{PON}, \mathrm{CaCO}_{3}$ and $\mathrm{SOD}$, the fixed factors were seasons with four levels (major and minor upwelling, major and minor non-upwelling) and exposure with two levels (exposed and sheltered), whereas bays (Chengue, Gayraca, Neguanje, and Cinto) were set as a random factor. For sedimentation variables, the fixed factors 
Table 1. Seasonal means of sedimentary parameters and univariate analyses. Significant PERMANOVA results are indicated by asterisks with * for significant $(p<0.05)$. Not significant values are displayed in italics. Abbreviations: exposed site (exp), sheltered site (she), particulate organic carbon (POC), particulate organic nitrogen (PON), chlorophyll $a$ (chl $a)$, and calcium carbonate $\left(\mathrm{CaCO}_{3}\right)$.

\begin{tabular}{|c|c|c|c|c|c|c|c|c|c|c|c|c|c|c|}
\hline \multirow[b]{2}{*}{ Variables/Sites } & \multicolumn{2}{|c|}{ Major upwelling } & \multicolumn{2}{|c|}{ Minor upwelling } & \multicolumn{2}{|c|}{ Major non-upwelling } & \multicolumn{2}{|c|}{ Minor non-upwelling } & \multicolumn{2}{|c|}{ Seasons } & \multicolumn{2}{|c|}{ Bays } & \multicolumn{2}{|c|}{ Exposure } \\
\hline & $\exp$ & she & $\exp$ & she & $\exp$ & she & $\exp$ & she & Pseudo- $F$ & (p) & Pseudo- $F$ & (p) & Pseudo- $F$ & (p) \\
\hline POC sedimentation $\left(\mathrm{mg} \mathrm{POC} \mathrm{m}^{-2} \mathrm{~d}^{-1}\right)$ & $623 \pm 193$ & $382 \pm 124$ & $532 \pm 95$ & $514 \pm 169$ & $399 \pm 63$ & $242 \pm 48$ & $406 \pm 190$ & $338 \pm 83$ & 17.410 & $0.029^{*}$ & - & - & 8.916 & $0.046^{*}$ \\
\hline PON sedimentation $\left(\mathrm{mg} \mathrm{PON} \mathrm{m}^{-2} \mathrm{~d}^{-1}\right)$ & $110 \pm 47$ & $63 \pm 19$ & $89 \pm 49$ & $77 \pm 25$ & $54 \pm 12$ & $32 \pm 9$ & $66 \pm 34$ & $49 \pm 12$ & 12.589 & $0.046^{*}$ & _ & _- & 6.661 & 0.099 \\
\hline Chl $a$ sedimentation ( $\mathrm{mg} \mathrm{chl} a \mathrm{~m}^{-2} \mathrm{~d}^{-1}$ ) & $66.4 \pm 41.2$ & $27.9 \pm 21.5$ & $27.6 \pm 9.0$ & $17.2 \pm 19.9$ & $8.5 \pm 5.0$ & $1.2 \pm 0.1$ & $12.2 \pm 8.8$ & $3.7 \pm 4.2$ & 7.853 & 0.057 & - & - & 2.558 & 0.193 \\
\hline Molar C: $N$ of supplied POM & $6.6 \pm 2.5$ & $7.3 \pm 1.3$ & $8.4 \pm 4.0$ & $8.0 \pm 2.2$ & $8.7 \pm 1.0$ & $8.0 \pm 4.5$ & $7.4 \pm 0.7$ & $8.1 \pm 1.4$ & 0.847 & 0.428 & - & - & 0.003 & 0.945 \\
\hline Relative proportion of chl $a$ in supplied POC (\%) & $0.15 \pm 0.11$ & $0.10 \pm 0.08$ & $0.07 \pm 0.02$ & $0.04 \pm 0.04$ & $0.03 \pm 0.02$ & $0.01 \pm 0.00$ & $0.04 \pm 0.02$ & $0.01 \pm 0.01$ & 6.892 & 0.159 & - & - & 1.593 & 0.292 \\
\hline Sedimentary POC $\left(\mathrm{mg} \mathrm{POC} \mathrm{g}^{-1}\right)$ & $2.06 \pm 0.57$ & $2.38 \pm 0.46$ & $2.14 \pm 0.38$ & $2.48 \pm 0.65$ & $2.51 \pm 0.77$ & $2.57 \pm 0.45$ & $1.90 \pm 0.36$ & $2.13 \pm 0.30$ & 3.628 & $0.040^{*}$ & 2.662 & 0.086 & 4.625 & $0.041^{*}$ \\
\hline Sedimentary PON $\left(\mathrm{mg} \mathrm{PON} \mathrm{g}^{-1}\right)$ & $0.31 \pm 0.09$ & $0.31 \pm 0.06$ & $0.33 \pm 0.09$ & $0.34 \pm 0.10$ & $0.39 \pm 0.10$ & $0.35 \pm 0.07$ & $0.31 \pm 0.07$ & $0.31 \pm 0.06$ & 1.987 & 0.148 & 4.041 & $0.027^{*}$ & 0.034 & 0.845 \\
\hline Sedimentary Chl $a\left(\mu \mathrm{g} \mathrm{chl} a \mathrm{~g}^{-1}\right)$ & $4.60 \pm 3.08$ & $7.56 \pm 4.23$ & $4.81 \pm 1.32$ & $4.99 \pm 2.26$ & $5.97 \pm 1.68$ & $5.20 \pm 1.69$ & $4.58 \pm 1.50$ & $5.29 \pm 1.56$ & 1.144 & 0.338 & 0.659 & 0.592 & 3.782 & $0.049^{*}$ \\
\hline Sediment $\mathrm{O}_{2}$ demand $\left(\mathrm{mmol} \mathrm{O}_{2} \mathrm{~m}^{-2} \mathrm{~d}^{-1}\right)$ & $10.6 \pm 6.1$ & $17.4 \pm 5.8$ & $14.3 \pm 6.3$ & $18.7 \pm 5.6$ & $15.1 \pm 6.9$ & $20.5 \pm 4.0$ & $12.3 \pm 6.1$ & $17.4 \pm 7.8$ & 1.653 & 0.179 & 1.986 & 0.138 & 16.676 & $0.001^{*}$ \\
\hline Sedimentary $\mathrm{CaCO}_{3}(\%)$ & $6.2 \pm 2.7$ & $8.5 \pm 2.7$ & $7.1 \pm 2.5$ & $8.4 \pm 2.6$ & $7.3 \pm 2.6$ & $8.5 \pm 2.6$ & $6.7 \pm 2.9$ & $8.3 \pm 2.9$ & 0.104 & 0.941 & 11.122 & $0.002^{*}$ & 4.537 & $0.047^{*}$ \\
\hline Porosity (\% wt /wt) & $37.5 \pm 9.7$ & $43.9 \pm 5.3$ & - & - & $35.4 \pm 10.4$ & $46.5 \pm 4.0$ & - & - & 0.003 & 0.956 & 0.666 & 0.603 & 4.404 & 0.052 \\
\hline Grain size $(\mu \mathrm{m})$ & $1006 \pm 352$ & $606 \pm 142$ & & & $940 \pm 407$ & $590 \pm 105$ & & & 0.080 & 0.756 & 1.335 & 0.315 & 6.715 & $0.040^{*}$ \\
\hline
\end{tabular}

were exposure (exposed vs. sheltered site) and season (upwelling vs. non-upwelling), while for sediment characterization parameters the fixed factors were exposure (exposed vs. sheltered site) and season (upwelling vs. nonupwelling) along with the random factor bay (Chengue, Gayraca, Neguanje, and Cinto). Correlations among sedimentary parameters and along the horizontal distance gradient between Santa Marta and the TNNP bays were identified by a Spearman's rank correlation (Tables 2, 3).

Multivariate analyses considered the sedimentary variables grain size, porosity, carbonate content of sediments, POC, PON, chl $a$, and SOD (Table 4). Prior to analyses, sedimentary variables were normalized by subtracting the mean and dividing by the standard deviation of each variable ( $z$ transformation), thereby enabling a comparison on the same scale where all means equal 0 and the standard deviations are 1 (Quinn and Keough, 2002). Euclidean similarity was used to obtain the resemblance matrix, and a type III sum of squares (partial, SS) was applied in order to calculate the significance levels under a reduced model for all PERMANOVA analyses. A principle coordinates ordination (PCO; Gower, 1966) was used to visualize the seasonal patterns of sedimentary variables, bays and exposure. The effects and correlations of sedimentary variables with both PCO axes were indicated as vectors.

Statistical analyses were conducted by the software PRIMER $^{\circledR}$ (Plymouth Routines in Multivariate Ecological Research; v 6.1.11 PRIMER-E Ltd., UK) and the PRIMER ${ }^{\circledR}$ add on PERMANOVA+ (v 1.0.1 PRIMER-E Ltd., UK). The software SigmaPlot 12.0 (Systat Software Inc) was used for graphical representation of data.

\section{Results}

Temporal variations for all data on organic matter supply to the sediments and sedimentary parameters of all bays are provided as supplementary material (Figs. S1-S5 in Supplement). The seasonal means at the exposed and sheltered sites for the TNNP bays Chengue, Gayraca, Neguanje and Cinto are also available as supplementary material (Tables S1-S4 in Supplement).

\subsection{Sedimentary organic matter supply}

Spatial differences. Generally, more POC, PON, and chl $a$ were supplied to the seafloor at the exposed site in Gayraca Bay (Figs. 2, 3), but only sedimentary POC supply had a significant difference between sites (Table 1). The mean molar POC : PON ratio was similar between the exposed (7.3) and the sheltered site (7.6) and without significant spatial difference (Table 1). The relative molar chl $a$ fraction of the total trapped POC was higher at the exposed $(0.11 \%)$ than at the sheltered site $(0.06 \%)$, but without significant difference (Table 1).

Temporal differences. Significantly higher rates of POC and PON sedimentation (Table 1) were measured during major upwelling with $502.5 \pm 201.3 \mathrm{mg}$ POC m${ }^{-2} \mathrm{~d}^{-1}$ (mean $\pm \mathrm{SD}$ - standard deviation) and $86.0 \pm 42.6 \mathrm{mg}$ PON m${ }^{-2} \mathrm{~d}^{-1}$ compared to major non-upwelling with $320.4 \pm 98.4$ POC and $42.0 \pm 15.1 \mathrm{mg} \mathrm{PON} \mathrm{m}^{-2} \mathrm{~d}^{-1}$, respectively. Rates were also high during minor upwelling with $523.1 \pm 129.6 \mathrm{mg}$ POC m${ }^{-2} \mathrm{~d}^{-1}$ and $82.8 \pm 36.8 \mathrm{mg}$ PON m$~^{-2} \mathrm{~d}^{-1}$ as compared to minor non-upwelling with $369.0 \pm 138.1$ POC and $56.7 \pm 25.1 \mathrm{mg}$ PON m$^{-2} \mathrm{~d}^{-1}$, respectively. Chl $a$ supplied to the sediment was generally higher during major $\left(47.2 \pm 37.8 \mathrm{mg}\right.$ chl $a \mathrm{~m}^{-2} \mathrm{~d}^{-1}$; mean $\pm \mathrm{SD})$ and minor $\left(22.4 \pm 15.6 \mathrm{mg}\right.$ chl $\left.a \mathrm{~m}^{-2} \mathrm{~d}^{-1}\right)$ upwelling as compared to major and minor non-upwelling $\left(4.9 \pm 5.1\right.$ and $7.6 \pm 7.8 \mathrm{mg} \mathrm{chl} a \mathrm{~m}^{-2} \mathrm{~d}^{-1}$, respectively).

The sedimentation rate of chl $a$ was positively correlated to sedimentation of POC and PON. Pulses of organic matter supply were particularly observed during major (December-April) and midyear (July-August) upwelling (Figs. 2, 3). Annual mean rates of organic matter supplied to the sediments interpolated over 14 months of monitoring were $200 \mathrm{~g} \mathrm{POC} \mathrm{m}^{-2} \mathrm{yr}^{-1}, 34 \mathrm{~g} \mathrm{PON} \mathrm{m}^{-2} \mathrm{yr}^{-1}$, and $16 \mathrm{~g}$ chl $a \mathrm{~m}^{-2} \mathrm{yr}^{-1}$ at the exposed site, and $136 \mathrm{~g} \mathrm{POC}^{-2} \mathrm{yr}^{-1}$,

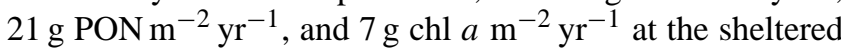
site, respectively. 

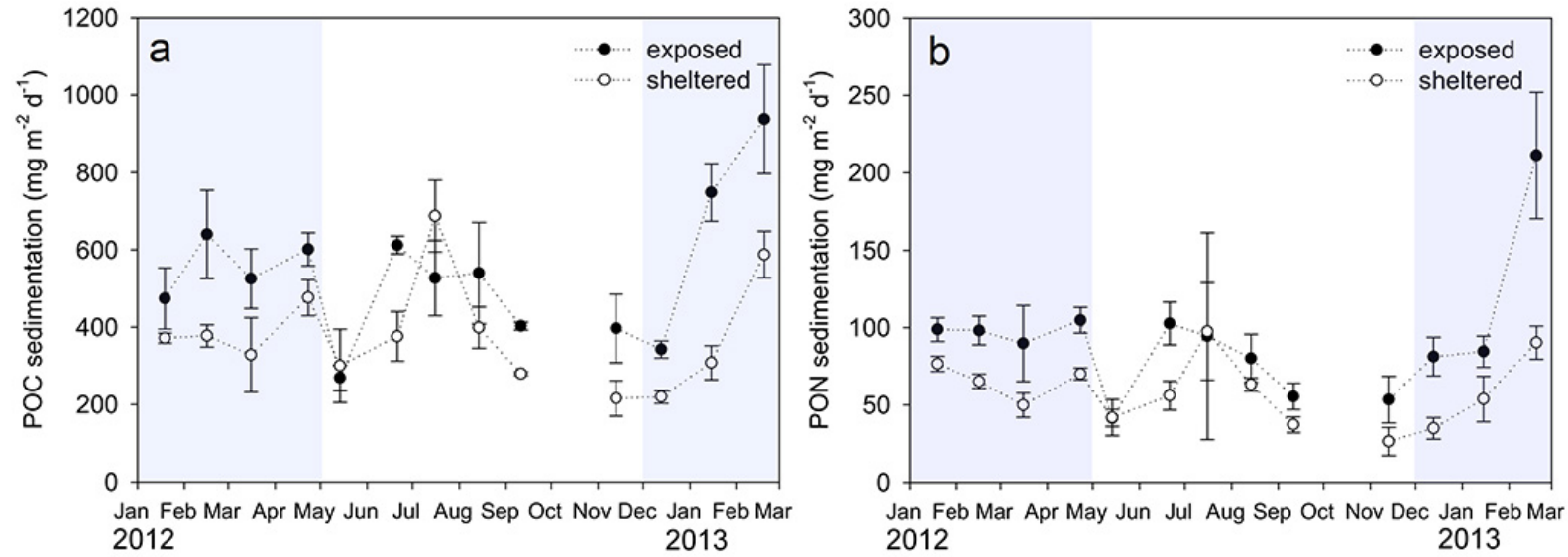

Figure 2. Sedimentary supply of POM to the seafloor. (a) Sedimentary POC; (b) sedimentary PON supply to the seafloor at an exposed and sheltered site in one exemplary bay in Tayrona National Natural Park (Gayraca). Upwelling periods are highlighted in blue. Abbreviations: particulate organic matter (POM), particulate organic carbon (POC), and particulate organic nitrogen (PON).

Table 2. Correlation matrix of environmental sedimentary parameters with distance to Santa Marta and seasonal resolution. Significance levels of correlation coefficients (Spearman's rank correlation) among environmental variables with distance to Santa Marta are indicated by asterisks with * for significant $(p<0.05)$. Not significant values are displayed in italics. Abbreviations as previously defined in Table 1 and sediment oxygen demand (SOD).

\begin{tabular}{lrrrrrrr}
\hline Seasons & \multicolumn{7}{c}{ Correlations with distance to Santa Marta } \\
\hline & $\mathrm{Chl} a$ & POC & PON & SOD & $\mathrm{CaCO}_{3}$ & Porosity & Grain size \\
\hline Major upwelling & $0.76^{*}$ & 0.66 & 0.11 & $0.76^{*}$ & 0.44 & 0.33 & -0.66 \\
Minor upwelling & 0.22 & 0.33 & 0.11 & 0.44 & 0.33 & 0.33 & -0.66 \\
Major non-upwelling & -0.44 & 0.11 & -0.11 & 0.44 & 0.33 & 0.55 & -0.44 \\
Minor non-upwelling & 0.22 & 0.55 & 0.11 & 0.44 & 0.44 & 0.55 & -0.44 \\
\hline
\end{tabular}

\subsection{Sedimentary status parameters}

Spatial differences. Sediments at the exposed sites were largely composed of well-moderately sorted, very coarse sands with a mean grain size of $973 \pm 374 \mu \mathrm{m}( \pm$ SD). Poorly sorted medium-coarse sands with significantly smaller grain sizes $(598 \pm 123 \mu \mathrm{m})$ were found at the sheltered sites (Table 1). The porosity at the exposed sites $(36.5 \pm 9.9 \%$ $\mathrm{wt} / \mathrm{wt}$; mean $\pm \mathrm{SD}$ ) was generally lower than at the sheltered sites $(45.2 \pm 4.8 \% \mathrm{wt} / \mathrm{wt})$. Carbonate contents were generally low and significantly higher (Table 1) at the sheltered $(8.4 \pm 2.7 \%$ dry weight; mean \pm SD $)$ than at the exposed sites $(6.7 \pm 2.7 \%)$ and indicated sediments mainly composed of silicate. Significant differences were observed between the bays (Table 1) with the highest carbonate content in Chengue $(10.1 \pm 1.2 \%)$, followed by Neguanje $(8.4 \pm 1.2 \%)$, Gayraca $(7.4 \pm 3.4 \%)$, and Cinto $(4.4 \pm 0.8 \%)$. POC in reef sediments was significantly different between sites of exposure (Table 1) with higher contents

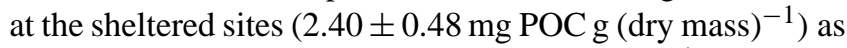
compared to the exposed $\left(2.14 \pm 0.60 \mathrm{mg} \mathrm{POC} \mathrm{g}^{-1}\right)$ sites. The highest PON content of $0.38 \pm 0.08 \mathrm{mg}$ PON g (dry mass) $)^{-1}$ was observed in sediments from Chengue Bay, followed by
Gayraca $\left(0.32 \pm 0.06 \mathrm{mg} \mathrm{PON} \mathrm{g}^{-1}\right)$, Cinto $(0.31 \pm 0.10 \mathrm{mg}$ PON g $\left.{ }^{-1}\right)$ and Neguanje $\left(0.29 \pm 0.06 \mathrm{mg} \mathrm{PON} \mathrm{g}^{-1}\right)$, however with significant difference (Table 1) only between Chengue and Neguanje. No significant differences in sedimentary PON contents were observed between the sites of different water-current-exposure (Table 1). Sedimentary chl $a$ was significantly higher (Table 1 ) at the sheltered sites $(6.42 \pm 3.51 \mu \mathrm{g} \operatorname{chl} a \mathrm{~g} \text { (dry mass })^{-1}$ than at the exposed sites $(4.91 \pm 2.49$, respectively). During major upwelling, sedimentary chl $a$ increased with decreasing distance to the rivers in the east (Table 2). The significant correlations along the distance gradient disappeared during non-upwelling, except for the positive correlation between distance to Santa Marta and carotenoids during munor non-upwelling (Table 2).

Temporal differences. No seasonal differences were observed for the sedimentary properties grain size, porosity and carbonate content (Table 1). Sedimentary grain size was negatively correlated to SOD, carbonate content and porosity of sediments (Table 3). Carbonate content was positively correlated to PON contents and porosity of sediments (Table 3 ). Sediment porosity was positively correlated to carbonate content, and highly negatively correlated to 
Table 3. Correlation matrix of environmental sedimentary parameters. Significance levels of correlation coefficients (Spearman's rank correlation) among sedimentary parameters and distance from Santa Marta are indicated by asterisks with * for significant $(p<0.05)$ and ${ }^{* *}$ for very significant $(p<0.01)$. Not significant correlations are displayed in italics. Abbreviations as previously defined in Table 1 and sediment oxygen demand (SOD).

\begin{tabular}{|c|c|c|c|c|c|c|c|}
\hline & Chl $a$ & PON & POC & SOD & $\mathrm{CaCO}_{3}$ & Porosity & Grain size \\
\hline Chl $a$ & & -0.16 & 0.11 & $0.39 *$ & 0.05 & 0.09 & -0.34 \\
\hline PON & & & $0.80^{* *}$ & 0.21 & $0.36^{*}$ & -0.03 & 0.11 \\
\hline POC & & & & $0.42 *$ & 0.32 & 0.20 & -0.16 \\
\hline SOD & & & & & 0.31 & 0.31 & $-0.37^{*}$ \\
\hline $\mathrm{CaCO}_{3}$ & & & & & & $0.69^{* *}$ & $-0.61^{* *}$ \\
\hline Porosity & & & & & & & $-0.90^{* *}$ \\
\hline
\end{tabular}

Table 4. Multivariate analyses: significant differences among environmental sedimentary parameters in Tayrona National Natural Park and multiple comparisons between seasons and bays. Main effects of multivariate analyses and the multiple comparisons between seasons (major upwelling, minor upwelling, major non-upwelling, and minor non-upwelling) and bays (Chengue, Gayraca, Neguanje, and Cinto) are shown for the parameters sedimentary chl $a, \mathrm{POC}, \mathrm{PON}, \mathrm{SOD}$, and $\mathrm{CaCO}_{3}$. Significant PERMANOVA results are indicated by asterisks with * for significant $(p<0.05)$ and ${ }^{* *}$ for very significant $(p<0.01)$. Not significant values are displayed in italics. Abbreviations as previously defined in Table 1 and sediment oxygen demand (SOD).

\begin{tabular}{lrrr}
\hline Factors & DF & Pseudo- $F$ & $(p)$ \\
\hline Seasons (fixed) & 3 & 1.234 & 0.286 \\
Bays (random) & 1 & 3.270 & $0.001^{* *}$ \\
Exposure (fixed) & 3 & 7.827 & $0.001^{* *}$ \\
Exposure × season & 3 & 0.770 & 0.643 \\
\hline Multiple comparisons between seasons & & $t$ & $(p)$ \\
Major upwelling - minor upwelling & 0.763 & 0.677 \\
Major upwelling - major non-upwelling & 1.260 & 0.247 \\
Major upwelling - minor non-upwelling & & 0.790 & 0.645 \\
Minor upwelling - major non-upwelling & & 0.830 & 0.576 \\
Minor upwelling - minor non-upwelling & & 0.809 & 0.616 \\
Major non-upwelling - minor non-upwelling & & 1.596 & 0.067 \\
\hline Multiple comparisons between bays & & $t$ & $(p)$ \\
Chengue - Gayraca & & 1.633 & 0.122 \\
Chengue - Neguanje & & 2.612 & $0.01^{* *}$ \\
Chengue - Cinto & 2.240 & $0.023^{*}$ \\
Gayraca - Neguanje & 1.341 & 0.203 \\
Gayraca - Cinto & & 1.247 & 0.195 \\
Neguanje - Cinto & 2.014 & $0.031^{*}$ \\
\hline
\end{tabular}

sedimentary grain size (Table 3 ). POC contents in reef sediments were significantly different between seasons (Table 1). The highest POC was measured during major non-upwelling $\left(2.54 \pm 0.63 \mathrm{mg}\right.$ POC g ${ }^{-1}$; mean \pm SD) and the lowest during minor non-upwelling $\left(2.02 \pm 0.35 \mathrm{mg} \mathrm{POC}^{-1}\right)$. Similar POC contents were measured during major $(2.23 \pm 0.54 \mathrm{mg}$ POC $\left.\mathrm{g}^{-1}\right)$ and minor (2.31 $\pm 0.56 \mathrm{mg}$ POC $\left.\mathrm{g}^{-1}\right)$ upwelling. Sedimentary POC was highly correlated to PON and was additionally positively correlated to SOD (Table 3 ). Sedimentary PON contents ranged between $0.31 \pm 0.08 \mathrm{mg} \mathrm{PON} \mathrm{g}^{-1}$ (mean $\pm \mathrm{SD}$ ) during major upwelling and $0.37 \pm 0.09 \mathrm{mg}$ PON g ${ }^{-1}$ during major non-upwelling, but without significant differences between seasons (Table 1). PON had a highly significant correlation with sedimentary POC and was positively correlated to carbonate content (Table 3). Concentrations of chl $a$ in marine sediments were significantly different between seasons (Table 1) with higher values during major $\left(6.12 \pm 3.99 \mu \mathrm{g}\right.$ chl $\left.a \mathrm{~g}^{-1}\right)$ upwelling and nonupwelling $\left(5.59 \pm 1.72 \mu \mathrm{g} \mathrm{chl} a \mathrm{~g}^{-1}\right)$ than compared to minor $\left(4.90 \pm 1.83 \mu \mathrm{g} \mathrm{chl} a \mathrm{~g}^{-1}\right)$ upwelling and non-upwelling $\left(4.92 \pm 1.56 \mu \mathrm{g}\right.$ chl $\left.a \mathrm{~g}^{-1}\right)$. Chl $a$ exhibited positive correlations with SOD (Table 3).

\subsection{Sedimentary $\mathrm{O}_{2}$ demand}

Spatial differences. Sedimentary $\mathrm{O}_{2}$ uptake was significantly higher (Table 1; Fig. 4) at the sheltered 


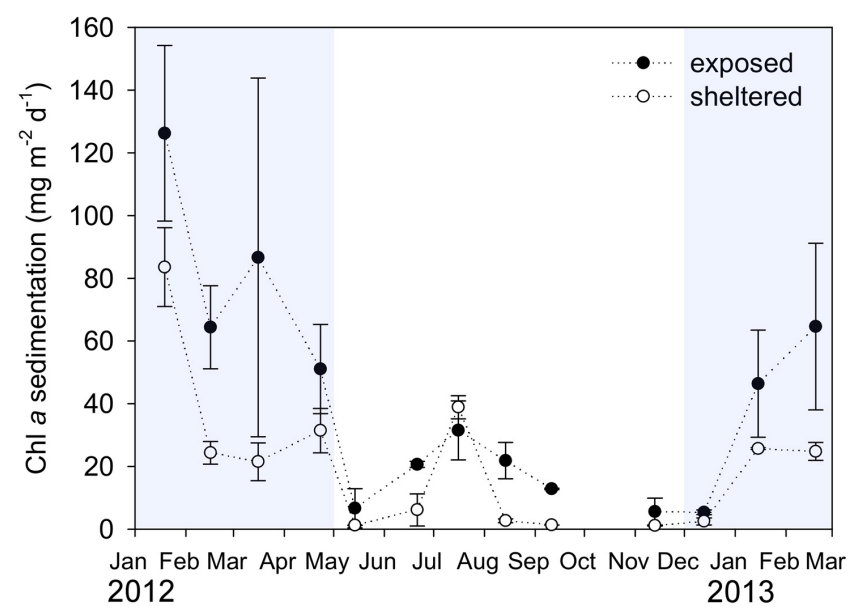

Figure 3. Sedimentary supply of chlorophyll $a$ (chl $a$ ) to the seafloor at an exposed and sheltered site in one exemplary bay in Tayrona National Natural Park (Gayraca). Major upwelling periods are highlighted in blue.

$\left(18.2 \pm 5.9 \mathrm{mmol} \mathrm{O}_{2} \mathrm{~m}^{-2} \mathrm{~d}^{-1}\right.$; mean $\left.\pm \mathrm{SD}\right)$ than at the exposed $\left(12.3 \pm 6.6 \mathrm{mmol} \mathrm{O}_{2} \mathrm{~m}^{-2} \mathrm{~d}^{-1}\right)$ sites. SOD had a positive correlation with distance gradient during major upwelling (Table 2).

Temporal differences. Seasonal differences had no effects on sedimentary SOD. SOD was positively correlated to $\operatorname{chl} a$ and POC, and negatively correlated to grain size of sediments (Table 3). Sedimentation of PON was positively correlated to POC supply, but negatively correlated to SOD.

\subsection{Spatiotemporal analysis}

Multivariate analyses taking into account the sedimentary parameters grain size distribution, porosity, carbonate content, sedimentary POC and PON, chl $a$, and SOD as variables showed that spatial differences were more pronounced than seasonal. While no significant seasonal differences were observed among the overall sedimentary parameters, significant spatial differences were present between sites with different exposure and bays (Table 4). Pair-wise comparisons revealed that the measured parameters were only significantly different between the seasons of major non-upwelling and minor non-upwelling (Table 4). Differences in sedimentary parameters between bays were significant between Chengue and Neguanje, Chengue and Cinto, and between Neguanje and Cinto (Table 4).

PCO ordination confirmed results of multivariate analyses showing that best separation was obtained by grouping the data in their (dis)similarity according to the degree of exposure between sites (Fig. 5c) as compared to seasons (Fig. 5a) and bays (Fig. 5b). Only during major upwelling were the parameters chl $a$ and SOD significantly positively correlated to the distance gradient between Santa Marta and the river months in the east, indicating that riverine discharge did not affect sedimentary parameters during the other seasons. The countercurrent-located city Santa Marta had no measurable effects on sedimentary properties.

\section{Discussion}

\subsection{Organic matter supply to reef sediments}

The organic matter supplied to TNNP reef sediments was generally higher at the wind-, wave- and water-currentexposed site and increased significantly during seasonal upwelling. The difference in exposure degrees between the opposing sites was addressed in previous studies (Bayraktarov et al. 2013, 2014b). Because of the design of the sediment traps, its short deployment duration of $48 \mathrm{~h}$, and visual inspection of the trap contents, we can largely exclude resuspension and trapping of benthic fauna. Our results therefore closely reflect the sedimentation of POM from the water column to the seafloor. The high contents of organic matter delivered to the sediments at the exposed site are likely the consequence of increased water mixing and transport processes by water currents (Alldredge and Silver, 1988; Kepkay, 1994). However, a higher accumulation of organic matter and consequently increased SOD were observed at the water-current-sheltered sites where the sedimenting material was allowed to settle due to lower hydrodynamics. The molar $\mathrm{C}: \mathrm{N}$ ratio of organic matter was above the Redfield ratio of 6.6 for fresh phytoplankton detritus (Redfield, 1958), but generally kept within the range of 6-8 for open ocean and intertidal flat phytoplankton (Canfield et al., 2005). Only during January did the $\mathrm{C}: \mathrm{N}$ ratio of organic matter supplied to the sediments decrease below 6.6, indicating a depletion of organic carbon and a relative enrichment in $\mathrm{N}$, supported by observations from cold, upwelling-rich regions that are governed by high turbidity and nutrient availability (Martiny et al., 2013a). Typically, during non-upwelling, the $\mathrm{C}: \mathrm{N}$ ratios exceeded 8 , which goes along with results from warm oligotrophic regions where inorganic nutrients are depleted (Martiny et al., 2013a). The $\mathrm{C}: \mathrm{N}$ ratio links the carbon and nitrogen cycles and yet the systematic regional variations in $\mathrm{C}: \mathrm{N}$ are not fully understood. Some authors suggest that variations in $\mathrm{C}: \mathrm{N}$ ratio are attributed to regional differences in environmental conditions and phytoplankton diversity while at least five $\mathrm{C}: \mathrm{N}$ ratio-driving mechanisms exist: (1) content of cellular $\mathrm{N}$ declines when cells are $\mathrm{N}$-limited leading to an increased $\mathrm{C}: \mathrm{N}$ ratio (Vrede et al., 2002); (2) lower cellular $\mathrm{C}: \mathrm{N}$ ratio is present for phytoplankton growing under low-light irradiance and high-nutrient availability (Cronin and Lodge, 2003); (3) negative relationship between $\mathrm{C}: \mathrm{N}$ and growth rate (Chalup and Law, 1990); (4) changes in phytoplankton community composition lead to variation in $\mathrm{C}: \mathrm{N}$ ratio (Martiny et al., 2013b); and (5) influence of detritus on $\mathrm{C}: \mathrm{N}$ ratio (Martiny et al., 2013b). While mechanisms (3), (4) and (5) cannot be excluded, the $\mathrm{C}: \mathrm{N}$ ratios of the 

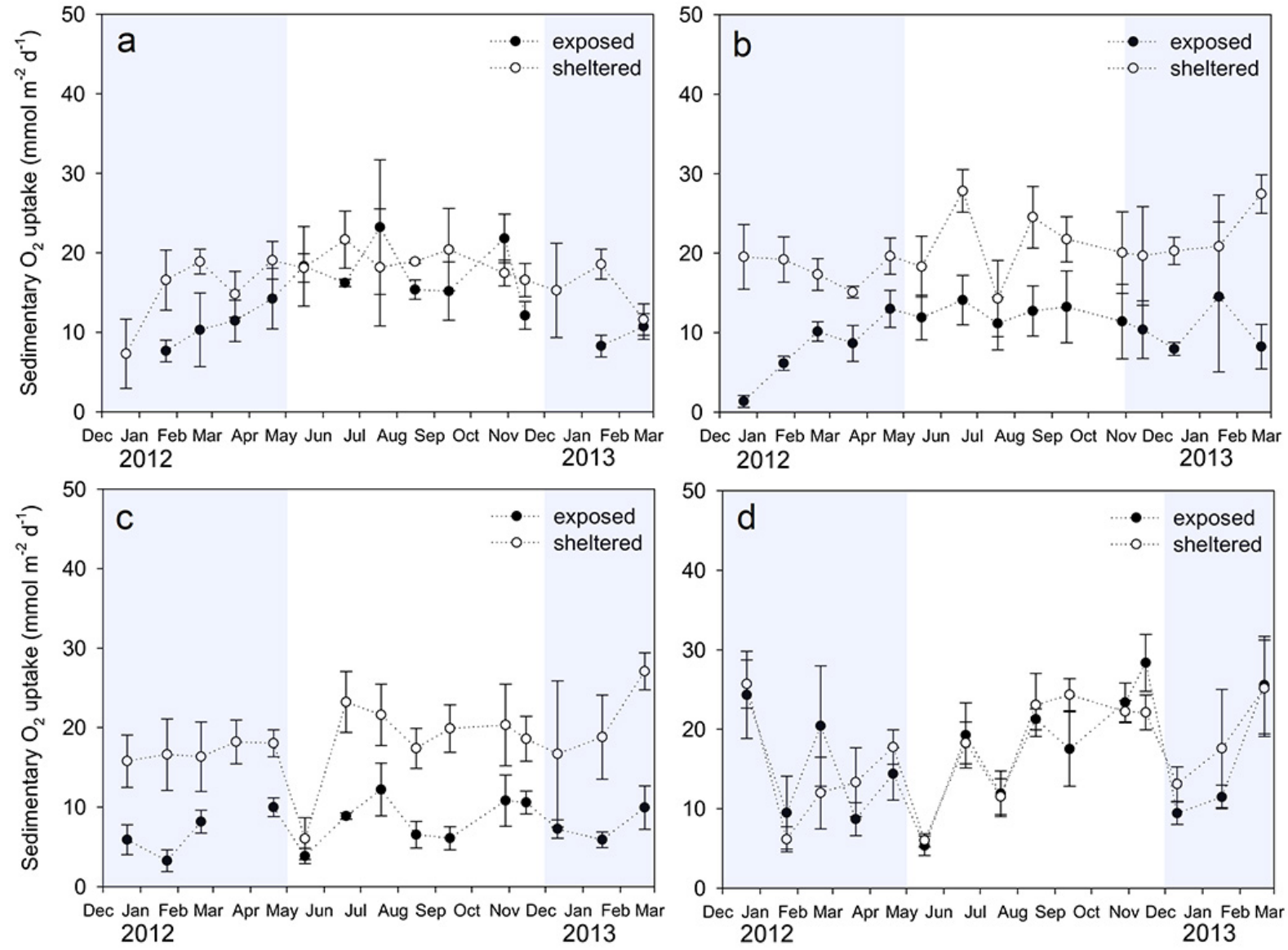

Figure 4. Sedimentary $\mathrm{O}_{2}$ uptake in Tayrona National Natural Park. Displayed are sedimentary $\mathrm{O}_{2}$ demand rates at an exposed site and a sheltered site in the bays (a) Chengue; (b) Gayraca; (c) Neguanje; and (d) Cinto. Major upwelling periods are highlighted in blue.

present study show a typical pattern characterized by light (typically decreased during upwelling due to higher turbidity; Bayraktarov et al., 2014a) and nutrient availability (increased during upwelling; Bayraktarov et al., 2013, 2014a).

During major and midyear upwelling, the sedimentation rates of chl $a$ exceeded typical values of $<15 \mu \mathrm{g} \mathrm{m}^{-2} \mathrm{~d}^{-1}$ reported for shallow oligotrophic coral reefs (e.g., Gulf of Aqaba, Red Sea; Wild et al., 2009) by $2-3$ orders of magnitude. The high amount of chl $a$ delivered to TNNP sediments is unique for coral reefs as it exceeded even sedimentation rates of chlorophyll after natural pulses of large amounts of organic matter, e.g., during mass coral spawning events ( $<3.0 \mathrm{mg} \mathrm{m}^{-2} \mathrm{~d}^{-1}$; Wild et al., 2008). These high rates of chl $a$ sedimentation may potentially be caused by extensive phytoplankton blooms triggered by enrichment of inorganic nutrient availability not only via upwelling (FrancoHerrera et al., 2006; Arévalo-Martínez and Franco-Herrera, 2008; García-Hoyos et al., 2010; Ramírez-Barón et al., 2010; Bayraktarov et al., 2013) but also via discharge of several smaller river mouths in the east of TNNP (Bayraktarov et al., 2014a).
The supply with organic carbon to the seafloor can range from $50 \mathrm{~g} \mathrm{C} \mathrm{m}^{-2} \mathrm{yr}^{-1}$ in oceanic areas, but may reach 200 $600 \mathrm{~g} \mathrm{C} \mathrm{m}^{-2} \mathrm{yr}^{-1}$ in coastal settings where nutrients are delivered by rivers, upwelling currents or water mixing (Bordenave, 1993). In TNNP, over $75 \%$ of the annual organic matter delivery was supplied during seasonal upwelling (December-April and July-August) to the sediments (79\% at the exposed site and $76 \%$ at the sheltered site). Annual POC sedimentation rates in TNNP were close to rates reported for Kaneohe Bay, Hawaii (179 $\mathrm{g} \mathrm{C} \mathrm{m}^{-2} \mathrm{yr}^{-1}$; Taguchi, 1982) and the Tuamotu Atoll lagoon, French Polynesia (128 $\mathrm{g} \mathrm{C} \mathrm{m}^{-2} \mathrm{yr}^{-1}$; Charpy and Charpy-Roubaud, 1991), higher than rates registered in Davies Reef, Great Barrier Reef, Australia (33-51 g C m ${ }^{-2} \mathrm{yr}^{-1}$; Hansen et al., 1992), but below rates measured in the southwest lagoon in New Caledonia (276 $\mathrm{g} \mathrm{C} \mathrm{m}^{-2} \mathrm{yr}^{-1}$; Clavier et al., 1995) or One Tree Island, Great Barrier Reef, Australia $\left(548 \mathrm{~g} \mathrm{C} \mathrm{m}^{-2} \mathrm{yr}^{-1}\right.$; Koop and Larkum, 1987). According to the amount of POC supplied to the sediments, the TNNP can be classified as mesotrophic (100-300 $\mathrm{g} \mathrm{C} \mathrm{m}^{-2} \mathrm{yr}^{-1}$; Nixon, 1995). This is the first data set on the spatial and temporal dynamics of 


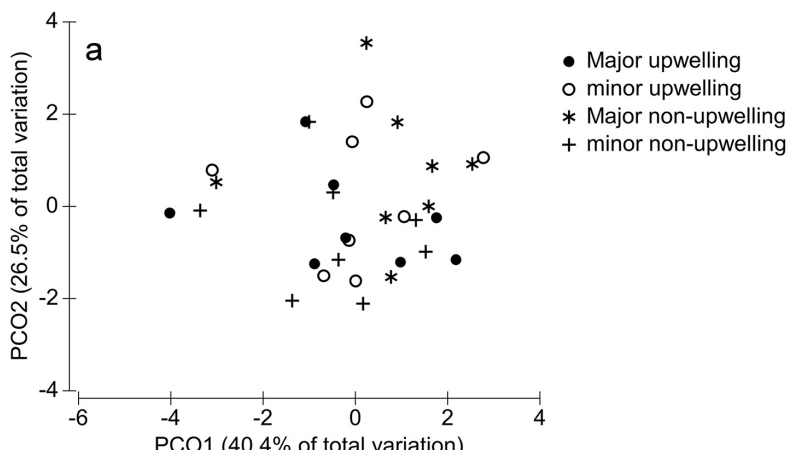

sites exhibited higher accumulation of POC and chl $a$. As a consequence, these sites had higher (more than $30 \%$ ) rates of SOD as compared to sites exposed to water currents. High rates of SOD indicate a rapid recycling of organic matter and reoxidation of reduced products of anaerobic respiration (Canfield, 1993).

Accumulation of organic matter is facilitated by slow decomposition in low-energy (characterized by low water current dynamics) fine-grained sediments (Bordenave, 1993) like at the sheltered sites of TNNP where significantly more organic carbon was measured. Our findings of higher accumulation of organic material at these sites are supported by several studies showing that fine-grained sediments usually carry high organic matter content and support a higher microbial biomass as compared to coarse sediments (Zobell, 1938; Newell, 1965; Meyer-Reil, 1986). A higher microbial biomass at the sheltered sites is confirmed by the increased SOD rates within these sediments. Especially calcareous reef sands are often associated with high numbers of heterotrophic microorganisms (Wild et al., 2006) involved in a rapid remineralization of organic matter (Rasheed et al., 2002; Wild et al., 2004a). However, reef sediments in TNNP had lower carbonate contents $(<11 \%)$ than reported for other reef areas (75-85\% for Gulf of Aqaba, Red Sea; Rasheed et al., 2003), and contents of supplied organic material were comparable to organic carbon in reef sediments composed of silicate ( $2.4 \mathrm{mg} \mathrm{g}^{-1}$; Rasheed et al., 2003). Accumulated organic carbon was below values reported for carbonate coral reefs (e.g., $3.6 \mathrm{mg} \mathrm{g}^{-1}$ for the Gulf of Aqaba, Red Sea (Rasheed et al., 2003), or 3.4-4.7 $\mathrm{mg} \mathrm{g}^{-1}$ for the Great Barrier Reef (Moriarty, 1982)). POC contents in TNNP sediments are in the range of typical values for shallow, oxygenated sediments of the shelf $\left(<5 \mathrm{mg} \mathrm{g}^{-1}\right.$; Bordenave, 1993; Jørgensen, 1996). Dell'Anno et al. (2002) observed that oligotrophic control sites in Mediterranean sediments had mean values of $<4 \mu \mathrm{g} \mathrm{chl} a \mathrm{~g}^{-1}$ and suggested this as a threshold for oligotrophic sediments. As the chl $a$ content in TNNP reef sediments oscillated slightly above this value $\left(4.9 \mu \mathrm{g}\right.$ chl $a \mathrm{~g}^{-1}$ during non-upwelling and $6.1 \mu \mathrm{g}$ chl $a \mathrm{~g}^{-1}$ during upwelling), they can be characterized as meso-oligotrophic.

5. Graphical representation of multivariate analyses resut by principle coordinates ordination (PCO). PCO of environmental sedimentary parameters was grouped by seasons (a), bays (b), and exposure to wave and water currents of the sampling locations (c). Effects and directions of environmental variables in (c) are displayed as vectors with the abbreviations particulate organic carbon (POC), particulate organic nitrogen (PON), chlorophyll $a$ (chl $a$ ) and sediment oxygen demand (SOD).

organic matter supplied to reef sediments in the Caribbean that are influenced by seasonal upwelling.

\subsection{Sedimentary properties}

Finer sediments with higher porosity and carbonate content were observed at water-current-sheltered sites in TNNP as compared to -exposed sites. The sediments at the sheltered

\subsection{Sedimentary oxygen consumption and organic carbon recycling}

Findings of the present study indicate that reef sediments of TNNP are very efficient in the degradation and recycling of organic matter supplied by the water column. The behavior of higher SOD in the finer sediments with higher porosity at sheltered locations in comparison to exposed sites is in agreement with the study of Alongi et al. (1996), who reported SOD of $10.5 \mathrm{mmol} \mathrm{m}^{-2} \mathrm{~d}^{-1}$ at sheltered sites compared to $2.1 \mathrm{mmol} \mathrm{m}^{-2} \mathrm{~d}^{-1}$ in the carbonate-rich sand of the exposed back-reef lagoon of Ningaloo Reef, Western Australia. The higher oxygen demand at the sheltered sites could 
be explained by a higher microbial biomass in the finer silicate sediments and/or by the accumulated detritus, which experiences a retention at these sites due to a restricted water circulation as suggested by Alongi et al. (1996). SOD in TNNP was in the range of $10-120 \mathrm{mmol} \mathrm{O}_{2} \mathrm{~m}^{-2} \mathrm{~d}^{-1}$ reported for permeable sediments of the continental shelf (Reimers et al., 2004; Rusch et al., 2006).

At the exposed site in Gayraca Bay, significantly more organic carbon was supplied than at the sheltered site. However, higher SOD at the sheltered sites indicated a more efficient remineralization of the supplied organic matter through a high microbial biomass and/or a better deposition of organic material due to lower water current dynamics. High SOD could be explained by high turnover rates that mainly depend on (1) the sediment properties and/or (2) the quality of supplied organic matter. Sediments at the exposed site are coarse, with lower porosity and continuously flushed by increased water current dynamics. Water currents may augment the advective transport of particulates and solutes through permeable sediments (Huettel et al., 2003; Rasheed et al., 2003; Precht and Huettel, 2004; Reimers et al., 2004), but they also may impede the deposition of organic matter on the sediment surface by turbulent mixing (Alongi et al., 1996). At the sheltered sites, the finer sediments are exposed to lower water current dynamics enabling the settlement of organic matter on the sediment surface. The decreased water flow here may facilitate advective porewater exchange to that extent, so that organic matter is comparably more recycled (Huettel et al., 2003), which could explain the significantly higher SOD rates at the sheltered sites as compared to the exposed sites. In addition to sediment properties, sediments of TNNP received organic matter with extremely high chl $a$ contents from phytoplankton detritus of a $\mathrm{C}: \mathrm{N}$ ratio between 6 and 8, representing an easily degradable, fresh organic material. Through their sediment properties and the upwellingtriggered supply with fresh organic matter, reef sediments of TNNP appear highly adapted to processing organic matter pulses triggered by seasonal upwelling and eutrophication events.

\subsection{Spatiotemporal influences and ecological perspective}

The findings of the present study indicate that the reef sediments in TNNP are rather controlled by location than by season. Water-current-sheltered sediments exhibited higher SOD rates after upwelling-induced pulses of organic matter sedimentation than sediments at exposed sites. The high SOD at the sheltered sites suggest a good pelagic-benthic coupling and processing of organic matter pulses during major and midyear upwelling.

Sedimentary chl $a$ and SOD increased significantly with decreasing distance to the eastern rivers during upwelling, while no correlation along this distance gradient was observed during non-upwelling, suggesting an effect of nutrient-enriched upwelling waters and riverine runoff from the east rather than an influence from the countercurrentlocated city of Santa Marta in the southwest. Correlations of seawater chl $a$ concentration and biological oxygen demand with this distance gradient were also observed for the water column; however, the correlations were present during nonupwelling and disappeared during upwelling (Bayraktarov et al., 2014a). Significantly increased chl $a$ concentrations with a mean value of $2.70 \mu \mathrm{g} \mathrm{L}^{-1}$ were observed during upwelling in TNNP seawater (Bayraktarov et al., 2014a), which may explain the higher rates of chl $a$ supply to the sediments, where also an accumulation of $\operatorname{chl} a$ was registered during this season.

Significant seasonal differences were observed for sedimentation rates of POC and PON, which increased during upwelling. Higher organic matter supply to the seafloor during upwelling is consistent with the reported higher phytoplankton growth (Franco-Herrera et al., 2006; ArévaloMartínez and Franco-Herrera, 2008; García-Hoyos et al., 2010; Ramírez-Barón et al., 2010) as a result of inorganic nutrient enrichment during this season (Salzwedel and Müller 1983; Bayraktarov et al., 2013; Bayraktarov et al., 2014a). While sedimentation rates of organic matter were higher during upwelling, incorporation of POC into the sediments was significantly increased during non-upwelling. In contrast to studies that reported pronounced seasonal effects on sedimentary properties (Clavier et al., 1995; Rusch et al., 2000), the multivariate analyses in the present study showed that location (exposed vs. sheltered) and the differences between bays had stronger effects on sedimentary parameters than seasonal change.

Sediment oxygen demand adjusted to the amount of supplied organic carbon and was always higher at the sheltered sites, characterizing them as major places for organic matter recycling in TNNP. These findings suggest fast recycling of organic matter with ensuing release of regenerated nutrients from the reef sediments. This in turn may fuel new benthic primary production. Our results show that the supply of organic matter to the sediments is controlled by phytoplankton production in the water column and is likely triggered by seasonal upwelling and riverine discharge. Rates of sedimentation of organic carbon, sedimentary organic matter, and chl $a$ concentrations suggest the marine sediments of TNNP as meso-oligotrophic. The present study thus indicates that the parameters sedimentation rate of organic carbon and sedimentary organic matter including chl $a$ contents are cost-effective biophysical indicators that are recommended to be included in regular monitoring activities of TNNP coral reefs.

\section{Author Contribution}

E. Bayraktarov and C. Wild designed the study and E. Bayraktarov collected the data. Analysis of data was 
performed by E. Bayraktarov The manuscript was prepared by E. Bayraktarov and C. Wild.

\section{The Supplement related to this article is available online at doi:10.5194/bg-11-2977-2014-supplement.}

Acknowledgements. We acknowledge J. F. Lazarus-Agudélo, J. R. Alarcón-Moscoso, V. Pizarro, L. A. Gómez-Lemos, B. Almonacil-Fernández, M. Maruri-Cruz, L. V. Carrillo-Pacheco, J. C. Vega-Sequeda, J. Rau, T. Lopez-Londoño, C. M. Díaz-Sanchez, and $\mathrm{C}$. Eidens for support during field trips and diving assistance. We thank the staff of Instituto de Investigaciones Marinas y Costeras (Invemar) in Santa Marta, especially D. I. Gómez-López and C. Jaramillo-Carvajal for organizational support, L. F. Espinosa and J. M. Betancourt for facilitating laboratory space, and F. J. Sánchez-Bonilla, C. A. Bolaño-Carillo and E. E. Vilarete-Salazar for logistics during field trips. We acknowledge the administration of the Tayrona National Natural Park for the kind collaboration. We thank D. Dassbach and M. Birkicht for their invaluable advice and support in the laboratory of the Leibniz Center for Tropical Marine Ecology as well as the assistants N. Garcia-Herrera, S. Schmalz, and H. O'Neill for their help in sample processing. The manuscript has been greatly improved by the valuable comments of the reviewers. This study was supported by the German Academic Research Service (DAAD) through the German-Colombian Center of Excellence in Marine Sciences (CEMarin) under coordination of B. Werding and T. Wilke.

Edited by: G. Herndl

\section{References}

Alldredge, A. L. and Silver, M. W.: Characteristics, dynamics and significance of marine snow, Prog. Oceanogr., 20, 41-82, 1988.

Alongi, D. M., Tirendi, F., and Goldrick, A.: Organic matter oxidation and sediment chemistry in mixed terrigenous-carbonate sands of Ningaloo Reef, Western Australia, Mar. Chem., 54, 203-219, 1996.

Anderson, M. J.: A new method for non-parametric multivariate analysis of variance, Austral Ecol., 26, 32-46, 2001.

Anderson, M. J., Gorley, R., and Clarke, K: PERMANOVA+ for PRIMER: guide to software and statistical methods. Plymouth, UK, PRIMER-E, 2008.

Andrade, C. A. and Barton, E. D.: The Guajira upwelling system, Cont. Shelf Res., 25, 1003-1022, 2005.

Arar, E. J.: Method 446.0: In vitro determination of chlorophylls $a$, $b, c_{1}+c_{2}$ and pheopigments in marine and freshwater algae by visible spectrophotometry, Ohio, p. 26, 1997.

Arar, E. J. and Collins, G. B.: Method 445.0: In vitro determination of chlorophyll $a$ and pheophytin $a$ in marine and freshwater algae by fluorescence, Ohio, p. 22, 1997.

Arévalo-Martínez, D. and Franco-Herrera, A.: Características oceanográficas de la surgencia frente a la Ensenada de Gaira, departamento del Magdalena, época seca menor de 2006, Bol. Invest. Mar. Cost., 37, 131-162, 2008.
Bayraktarov, E., Eidens, C., Pizarro, V., Wilke, T., and Wild, C.: Bleaching susceptibility and recovery of Colombian Caribbean corals in response to water current exposure and seasonal upwelling, PLoS ONE, 8, e80536, doi:10.1371/journal.pone.0080536, 2013.

Bayraktarov, E., Pizarro, V., and Wild, C.: Spatial and temporal variability of water quality in the coral reefs of Tayrona National Natural Park, Colombian Caribbean. Environ. Monit. Assess., 186, 3641-3659, 2014a.

Bayraktarov, E., Bastidas-Salamanca, M. L., and Wild, C. The physical environment in coral reefs of the Tayrona National Natural Park (Colombian Caribbean) in response to seasonal upwelling, Bol. Invest. Mar. Cost., in press, 2014b.

Bordenave, M.L.: The sedimentation of organic matter. In Applied petroleum geochemistry, 1st Edn., Editions Technip, 1720, 1993.

Boucher, G., Clavier, J., and Garrigue, C.: Oxygen and carbondioxide fluxes at the water-sediment interface of a tropical lagoon, Mar. Ecol. Prog. Ser., 107, 185-193, 1994.

Bula-Meyer, G.: Altas temperaturas estacionales del agua como condición disturbadora de las macroalgas del Parque Nacional Natural Tairona, Caribe colombiano: una hipótesis, An. Inst. Invest. Mar. Punta de Betín, 19/20, 9-21, 1990.

Calvert, S. E.: Oceanographic controls on the accumulation of organic matter in marine sediments, Geol. Soc., London, Spec. Publ., 26, 137-151, 1987.

Canfield, D. E.: Factors influencing organic carbon preservation in marine sediments, Chem. Geol., 114, 315-329, 1994.

Canfield, D. E., Kristensen, E., and Thamdrup, B.: Heterotrophic carbon metabolism, in: Advances in marine biology, San Diego, Elsevier Academic Press, 48, 129-162, 2005.

Capone, D. G., Dunham, S. E., Horrigan, S. G., and Duguay, L. E.:Microbial nitrogen transformations in unconsolidated coral reef sediments, Mar. Ecol. Prog. Ser., 80, 75-88, 1992.

Chalup, M. S. and Laws, E. A.: A test of the assumptions and predictions of recent microalgal growth models with the marine phytoplankter Pavlova lutheri, Limnol. Oceanogr., 35, 583-596, 1990.

Charpy, L. and Charpy-Roubaud, C. J.: Particulate organic matter fluxes in a Tuamotu atoll lagoon (French Polynesia), Mar. Ecol. Prog. Ser., 71, 53-63, 1991.

Clavier, J., Chardy, P., and Chevillon, C.: Sedimentation of particulate matter in the south-west lagoon of New Caledonia: Spatial and temporal patterns, Estuar. Coast. Shelf Sci., 40, 281-294, 1995.

Cronin, G. and Lodge, D. M.: Effects of light and nutrient availability on the growth, allocation, carbon/nitrogen balance, phenolic chemistry, and resistance to herbivory of two freshwater macrophytes, Oecologia, 137, 32-41, 2003.

Crossland, C. J. and Barnes, D. J.: Dissolved nutrients and organic particulates in water flowing over coral reefs at Lizard-Island, Aust. J. Mar. Freshw. Res., 34, 835-844, 1983.

Dell'Anno, A., Mei, M.L., Pusceddu, A., and Danovaro, $\mathrm{R}$ :Assessing the trophic state and eutrophication of coastal marine systems: a new approach based on the biochemical composition of sediment organic matter, Mar. Pollut. Bull., 44, 611-622, 2002. 
Departamento Administrativo Nacional de Estadística (DANE): Colombia - Censo General 2005, Nivel Nacional, Bogotá, Colombia, p. 489, 2005.

Diaz-Pulido, G. and Garzón-Ferreira, J.: Seasonality in algal assemblages on upwelling-influenced coral reefs in the Colombian Caribbean, Bot. Mar., 45, 284-292, 2002.

Fabricius, K. E.: Effects of terrestrial runoff on the ecology of corals and coral reefs: review and synthesis, Mar. Pollut. Bull., 50, 12546, 2005.

Fenchel, T., King, G. M., and Blackburn, T. H.:Bacterial biogeochemistry: the ecophysiology of mineral cycling, in: Bacterial biogeochemistry, San Diego, Academic Press, p. 307, 1998.

Franco-Herrera, A., Castro, L., and Tigreros, P. C.: Plankton dynamics in the south-central Caribbean Sea: strong seasonal changes in a coastal tropical system, Caribb. J. Sci., 42, 24-38, 2006.

García-Hoyos, L. M., Franco-Herrera, A., Ramírez-Barón, J. S., and López-Cerón, D. L.: Dinámica océano-atmosfera y su influencia en la biomasa fitoplanctónica, en la zona costera del Departamento del Magdalena, Caribe colombiano, Bol. Invest. Mar. Cost., 39, 307-335, 2010.

Glud, R. N., Eyre, B. D., and Patten, N.: Biogeochemical responses to mass coral spawning at the Great Barrier Reef?: Effects on respiration and primary production, Limnol. Oceanogr., 53, 10141024, 2008.

Glynn, P. W.: Bioerosion and coral-reef growth: a dynamic balance, in: Life and death of coral reefs, edited by: Birkeland, C., New York, Chapman and Hall, 68-94, 1997.

Gower, J. C.: Some distance properties of latent root and vector methods used in multivariate analysis, Biometrika, 53, 325-338, 1966.

Hallock, P.: Reefs and reef limestones in Earth history, in: Life and death of coral reefs, edited by: Birkeland, C., Berlin, Springer, 13-42, 1997.

Hansen, J. A., Klumpp, D. W., Alongi, D. M., Dayton, P. K., and Riddle, M. J.: Detrital pathways in a coral reef lagoon, Mar. Biol., 113, 363-372, 1992.

Hatcher, B. G.: Coral reef primary productivity: a beggar's banquet, Trends Ecol. Evol., 3, 106-111, 1988.

Hedges, J. I., Clark, W. A., and Cowie, G. L.: Organic matter sources to the water column and surficial sediments of a marine bay, Limnol. Oceanogr., 33, 1116-1136, 1988.

Henrichs, S. M.: Early diagenesis of organic matter in marine sediments: progress and perplexity, Mar. Chem., 39, 119-149, 1992.

Henrichs, S. M. and Reeburgh, W. S.: Anaerobic mineralization of marine sediment organicmatter: rates and the role of anaerobic processes in the oceanic carbon economy, Geomicrobiol. J., 5, 191-237, 1987.

Higgins, R. P. and Thiel, H.:Introduction to the study of meiofauna, Smithsonian Institution Press, p. 488, 1988.

Huettel, M., Røy, H., Precht, E., and Ehrenhauss, S.: Hydrodynamical impact on biogeochemical processes in aquatic sediments, Hydrobiologia, 494, 231-236, 2003.

Huettel, M., Berg, P., and Kostka, J. E.: Benthic exchange and biogeochemical cycling in permeable sediments, Annu. Rev. Mar. Sci., 6, 23-51, 2014.

Invemar: Sistema de Información Ambiental Marina de Colombia. (SIAM). Santa Marta, Colombia, Invemar, 2012.

Jeffrey, S. W. and Humphrey, G. F.: New spectrophotometric equations for determining chlorophylls $a_{1}, b_{1}, c_{1}$ and $c_{2}$ in higher plants, algae and natural phytoplankton, Biochem. Physiol. Pfl., 167, 191-194, 1975.

Jørgensen, B. B.: Processes at the sediment water interface, in: The major biogeochemical cycles and their interactions, edited by: Bolin, B. and Cook, R. B., Wiley, 477-509, 1983.

Jørgensen, B. B.: Material flux in the sediment, in: Eutrophication in coastal marine ecosystems, American Geophysical Union, 115135, 1996.

Jørgensen, B. B. and Revsbech, N. P.: Oxygen uptake, bacterial distribution, and carbon-nitrogen-sulfur cycling in sediments from the baltic sea - North sea transition, Ophelia, 31, 29-49, 1989.

Kepkay, P. E.: Particle aggregation and the biological reactivity of colloids, Mar. Ecol. Prog. Ser., 109, 293-304,1994.

Kleypas, J. A., McManus, J. W., and Meñez, L. A. B.: Environmental limits to coral reef development: Where do we draw the line?, Integr. Comp. Biol., 39, 146-159, 1999.

Köster, M., Babenzien, H-D., Black, H. J., Dahlke, S., Gerbersdorf, S., Meyercordt, J. ,Meyer-Reil,L-A., Rieling, T., Stodian, I., and Voigt,A.:Significance of aerobic and anaerobic mineralization processes of organic carbon in sediments of a shallow coastal inlet in the southern Baltic Sea, Proc. Mar. Sci., 2, 185194, 2000.

Koop, K. and Larkum, A. W. D.: Deposition of organic material in a coral reef lagoon, One Tree Island, Great Barrier Reef, Estuar. Coast. Shelf Sci., 25, 1-9,1987.

Kühl, M. and Jørgensen. B. B.: The light field of microbenthic communities: radiance distribution and microscaleoptics of sandy coastal sediments, Limnol. Oceanogr., 39, 1368-1398, 1994.

Martiny, A. C., Vrugt, J. A., Primeau,F. W., and Lomas M. W.: Regional variation in the particulateorganic carbon to nitrogen ratio in the surface ocean, Global Biogeochem. Cy., 27, 723-731, 2013a.

Martiny, A. C., Pham, C. T. A., Primeau, F. W., Vrugt, J. A., Moore, J. K., Levin, S. A., and Lomas, M. W.: Strong latitudinal patterns in the elemental ratios of marine plankton and organic matter, Nat. Geosci., 6, 279-283, 2013 b.

Meyer-Reil,L. A.: Spatial and temporal distribution of bacterial populations in marine shallow water surface sediments, in: Biogeochemical processes at the land-sea boundary, edited by: Lasserre, P. and Martin, J. M., Amsterdam, Elsevier, 43, 141160, 1986.

Moriarty, D. J. W.: Feeding of Holothuria atra and Stichopus chloronotus on bacteria, organic carbon and organic nitrogen in sediments of the Great Barrier Reef, Aust. J. Mar. Freshw. Res., 33, 255-263, 1982.

Newell, R.: The role of detritus in the nutrition of two marine deposit feeders, the prosobranch Hydrobia ulvae and the bivalve Macoma balthica, Proc. Zool. Soc. Lond., 144, 25-45, 1965.

Nieuwenhuize, J., Maas, Y. E., and Middelburg, J. J.: Rapid analysis of organic carbon and nitrogen in particulate materials. Mar. Chem., 45, 217-224, 1994.

Nixon, S. W.: Remineralization and nutrient cycling in coastal marine ecosystems, in: Nutrients and Estuaries, edited by: Neilson, B. J. and Cronin, L. E., New York, Humana Press, 111-138, 1981.

Nixon, S. W. Coastal marine eutrophication: a definition, social causes, and future concerns, Ophelia, 41, 199-219, 1995. 
Paramo, J., Correa, M., and Núñez, S.: Evidencias de desacople físico-biológico en el sistema de surgencia en La Guajira, Caribe colombiano, Rev. Biol. Mar. Oceanog., 46, 421-430, 2011.

Precht, E. and Huettel, M.: Rapid wave-driven advective pore water exchange in a permeable coastal sediment, J. Sea Res., 51, 93107,2004

Quinn, G. P. and Keough, M. J.: Experimental design and data analysis for biologists, Cambridge, Cambridge University Press, 2002.

Ramírez-Barón, J. S., Franco-Herrera, A., García-Hoyos, L. M., and López, D. A.: La comunidad fitoplanctónica durante eventos de surgencia y no surgencia, en la zona costera del Departamento del Magdalena, Caribe colombiano, Bol. Invest. Mar. Cost., 39, 233-253, 2010.

Rasheed, M., Badran, M. I., Richter, C., and Huettel, M.: Effect of reef framework and bottom sediment on nutrient enrichment in a coral reef of the Gulf of Aqaba, Red Sea. Mar. Ecol. Prog. Ser., 239, 277-285, 2002.

Rasheed, M., Badran, M. I., and Huettel, M.: Particulate matter filtration and seasonal nutrient dynamics in permeable carbonate and silicate sands of the Gulf of Aqaba, Red Sea, Coral Reefs, 22, 167-177, 2003.

Rasmussen, H. and Jørgensen, B. B.: Microelectrode studies of seasonal oxygen uptake in a coastal sediment: Role of molecular diffusion, Mar.Ecol.Prog.Ser., 81, 289-303, 1992.

Reimers, C. E., Stecher, H. A., Taghon, G. L., Fuller, C. M., Huettel, M., Rusch, A., Ryckelynck, N., and Wild, C.: In situ measurements of advective solute transport in permeable shelf sands, Cont. Shelf Res., 24, 183-201, 2004.

Redfield, A. C.: The biological control of chemical factors in the environment, Am. Sci., 46, 205-221, 1958.

Rusch, A., Huettel, M., and Forster, S.: Particulate organic matter in permeable marine sands - dynamics in time and depth, Estuar. Coast. Shelf Sci., 51, 399-414, 2000.

Rusch, A., Huettel, M., Wild, C., and Reimers, C. E.: Benthic oxygen consumption and organic matter turnover in organic-poor, permeable shelf sands, Aquat. Geochem., 12, 1-19, 2006.

Salzwedel, H. and Müller, K.: A summary of meteorological and hydrological data from the bay of Santa Marta, Colombian Caribbean, An. Inst. Inv. Mar. Punta de Betín, 13, 67-83, 1983.

Sansone, F. J., Andrews, C. C., and Okamoto, M. Y.: Adsorption of short-chain organic acids onto nearshore marine sediments, Geochim. Cosmochim. Acta, 51, 1889-1896, 1987.

Sorokin, Y. I.: Coral reef ecology, Berlin, Springer-Verlag, 1993.

Taguchi, S.: Sedimentation of newly produced particulate organic matter in a subtropical inlet, Kaneohe Bay, Hawaii, Estuar. Coast. Shelf Sci., 14, 533-544, 1982.

Veron, J.: Corals of the world, Townsville, Australia: Australian Institute of Marine Science, 1st Edn., 1-463, 2000.

Vrede, K., Heldal, M., Norland, S., and Bratbak, G.: Elemental composition $(\mathrm{C}, \mathrm{N}, \mathrm{P})$ and cell volume of exponentially growing and nutrient-limited bacterioplankton, Appl. Environ. Microbiol., 68, 2965-2971, 2002.

Wakeham, S. G., Lee, C., Hedges, J. I., Hernes, P. J., and Peterson, M. J.: Molecular indicators of diagenetic status in marine organic matter, Geochim. Cosmochim. Acta, 61, 5363-5369, 1997.
Wang, X. and Lee, C.: The distribution and adsorption behavior of aliphatic amines in marine and lacustrine sediments, Geochim. Cosmochim. Acta, 54, 2759-2774, 1990.

Wear, R. J. and Tanner, J. E.: Spatio-temporal variability in faunal assemblages surrounding the discharge of secondary treated sewage, Est. Coast. Mar. Sci., 73, 630-638, 2007.

Webb, J. E. and Theodor, J.: Irrigation of submerged marine sands through wave action, Nature, 220, 682-683, 1968.

Werding, B. and Sánchez, H.: The coral formations and their distributional pattern along a wave exposure gradient in the area of Santa Marta, Colombia, Medio Ambiente, 10, 61-68, 1989.

Werner, U., Bird, P., Wild, C., Ferdelman, T. G., Polerecky, L., Eickert, G., Jonstone, R., Hoegh-Guldberg, O., and de Beer, D.:Spatial patterns of aerobic and anaerobic mineralization rates and oxygen penetration dynamics in coral reef sediments, Mar. Ecol. Prog. Ser., 309, 93-105, 2006.

Wild, C., Huettel, M., Klueter, A., Kremb, S. G., Rasheed, M. Y. M., and Jørgensen, B. B.: Coral mucus functions as an energy carrier and particle trap in the reef ecosystem, Nature, 428, 6670, 2004a.

Wild, C., Rasheed, M., Werner, U., Franke, U., Johnstone, R., and Huettel, M.: Degradation and mineralization of coral mucus in reef environments, Mar. Ecol. Prog. Ser., 267, 159-171, $2004 \mathrm{~b}$.

Wild, C., Woyt, H., and Huettel, M.: Influence of coral mucus release on nutrient fluxes in carbonate sands, Mar. Ecol. Prog. Ser., 287, 87-98, 2005a.

Wild, C., Rasheed, M., Jantzen, C., Cook, P., Struck, U., Huettel, M., and Boetius, A.: Benthic metabolism and degradation of natural particulate organic matter in silicate and carbonate sands of the Northern Red Sea, Mar. Ecol. Prog. Ser., 298, 69-78, 2005b.

Wild, C., Laforsch, C., and Huettel, M.: Detection and enumeration of microbial cells in highly porous carbonate reef sands, Mar. Freshw. Res., 57, 415-420, 2006.

Wild, C., Jantzen, C., Struck, U., Hoegh-Guldberg, O., and Huettel, M.: Biogeochemical responses following coral mass spawning on the Great Barrier Reef: pelagic-benthic coupling, Coral Reefs, 27, 123-132, 2008.

Wild, C., Naumann, M. S., Haas, A., Struck, U., Mayer, F. W., Rasheed, M. Y. M., and Huettel, M. Coral sand $\mathrm{O}_{2}$ uptake and pelagic-benthic coupling in a subtropical fringing reef , Aqaba , Red Sea. Aquat. Biol., 6, 133-142, 2009.

Wild, C., Niggl, W., Naumann, M. S., and Haas, A. F.: Organic matter release by Red Sea coral reef organisms: potential effects on microbial activity and in situ $\mathrm{O}_{2}$ availability, Mar. Ecol. Prog. Ser., 411, 61-71, 2010.

Wollast, R.: The coastal organic carbon cycle: fluxes, sources, and sinks, in: Ocean margin processes in global change, edited by: Manroura, R. F. C., Martin, J.-M., and Wollast, R., Chichester, John Wiley and Sons, 365-381, 1991.

Zobell, C. E.: Studies on the bacterial flora of marine bottom sediments, J. Sediment. Res., 8, 10-18, 1938. 